\title{
Sistem Pakar Diagnosa Penyakit Mata dengan Fuzzy Logic dan Naïve Bayes
}

\author{
Putu Ananta Dama Putra, I Ketut Adi Purnawan, Desy Purnami Singgih Putri \\ Jurusan Teknologi Informasi, Fakultas Teknik, Universitas Udayana \\ Bukit Jimbaran, Bali, Indonesia, telp. (0361) 701806 \\ e-mail: suryasaputra007@gmail.com, dosenadi@yahoo.com, desysinggihputri@gmail.com
}

\begin{abstract}
Abstrak
Penyakit mata merupakan penyakit yang mengganggu penglihatan manusia. Penyakit mata dapat menyerang siapa saja baik orang tua maupun anak-anak. Penyakit mata jika ditangani secara dini maka semakin kecil kemungkinan penyakit untuk menjadi lebih parah, sehingga dibuatlah sistem pakar pada penelitian ini yang bertujuan mempermudah deteksi dini penyakit mata. Sistem Pakar Diagnosa Penyakit Mata dikembangkan menggunakan 16 gejala untuk menentukan 10 penyakit pada Mata. Metode yang digunakan adalah Fuzzy Logic dan Naïve Bayes. Fuzzy Logic digunakan untuk mengubah nilai tidak pasti yang diberikan oleh pasien menjadi nilai pasti selanjutnya diproses dengan Naïve Bayes yang berfungsi untuk menghitung bobot semua jawaban yang diberikan oleh pasien. Hasil tertinggi dari perhitungan menunjukkan penyakit yang diderita oleh pasien. Uji coba penelitian sistem pakar dilakukan pada 12 pasien dengan penyakit mata. Hasil uji coba kemudian dikomparasi dan diberikan bobot oleh Dokter Spesialis Penyakit Mata sehingga menghasilkan tingkat kemiripan antara sistem pakar dengan pakar aslinya sebesar $81 \%$.
\end{abstract}

Kata kunci: Penyakit Mata, Fuzzy Logic, Naïve Bayes, Sistem Pakar

\begin{abstract}
Eye disease is a disease that can interfere with human vision. Eye disease can affect anyone both parents and children. Eye disease if treated early, the less likely the disease to become more severe, so expert system was created in this study which aims to facilitate early detection of eye diseases. Expert systems were developed using 16 symptoms to determine 10 eye disease. The method used is Fuzzy Logic and Naïve Bayes. The Fuzzy Logic method is used to change the uncertain value given by the patient to a certain value so that it can be forwarded by the Naivve Bayes method that serves to calculate all the answers given by the patient. The patient answers all the questions given by the system. The highest results of the calculations show the illness suffered by the patient. The trials of experimental expert system are conducted to twelve patients with eye disease. The final results of the study were then compared and weighted by Eye Disease Specialists so as to produce a level of similarity between the expert system and the original expert in the amount of $81 \%$.
\end{abstract}

Keywords: Eye, Fuzzy Logic, Naïve Bayes, Expert System

\section{Pendahuluan}

Teknologi informasi dapat digunakan di segala bidang seperti perkantoran, bisnis, perhotelan, pendidikan serta kesehatan. Teknologi informasi juga terdapat dalam berbagai macam bentuk salah satunya adalah Sistem Informasi. Sistem informasi adalah seperangkat komponen yang memiliki keterkaitan antara satu dan lainnya serta berfungsi untuk mengumpulkan, memproses, menyimpan dan mendistribusikan informasi [1]. Sistem pakar adalah salah satu bentuk dari sistem informasi yang dapat dimanfaatkan untuk mengoptimalkan kinerja dokter dalam menangani suatu penyakit serta meningkatkan kualitas layanan untuk pasien termasuk deteksi dini pada penyakit [2]. Kelebihan sistem pakar di bidang kesehatan melatarbelakangi pengembangan sistem pakar pada penelitian ini yang diterapkan pada penyakit mata. Penyakit mata adalah penyakit yang dapat mengganggu penglihatan manusia. Penyakit mata dapat menyerang siapa saja baik orang tua maupun anak-anak. Penyakit mata jika ditangani secara dini maka semakin kecil kemungkinan penyakit untuk menjadi lebih parah. Sistem pakar yang dikembangkan bertujuan untuk mempermudah deteksi dini penyakit mata.

Sistem Pakar Diagnosa Penyakit Mata dikembangkan dengan Metode Fuzzy Logic dan Naïve Bayes. Pasien diharuskan untuk menjawab semua pertanyaan yang diberikan oleh 
sistem yang dirancang. Metode Fuzzy Logic digunakan untuk mengubah nilai tidak pasti yang diberikan oleh pasien menjadi nilai pasti sehingga dapat diproses lebih lanjut dengan Metode Naïve Bayes yang berfungsi untuk menghitung semua bobot jawaban yang diberikan oleh pasien. Sistem pakar yang dikembangkan dilengkapi penjelasan singkat penyakit serta solusi penanganan awal dari penyakit yang diderita pasien.

Penelitian dengan judul Sistem Pakar Penyakit pada Abdomen dengan Certain Factor oleh I Gusti Ayu Nyoman Agung Intan Maya Prawita adalah salah satu penelitian terkait sistem pakar yang membahas tentang sistem pakar untuk mendiagnosa penyakit pada abdomen. Metode yang digunakan adalah Certain Factor. Perbedaan sistem pakar diagnosa penyakit abdomen dengan sistem pakar diagnosa penyakit mata yang dikembangkan terletak pada metode yang digunakan. Sistem pakar diagnosa penyakit abdomen menggunakan Metode Fuzzy Logic dan Certain Factor untuk melacak gejala yang dialami dan mencocokkan gejala dengan aturan yang ada untuk menghasilkan diagnosa [3]. Sistem pakar diagnosa penyakit mata menggunakan Metode Naïve Bayes dan Fuzzy Logic untuk menghitung bobot semua jawaban yang diberikan pasien untuk menghasilkan diagnosa.

\section{Metodologi Penelitian}

Metode penelitian membahas mengenai tahapan akuisisi pengetahuan untuk menjadi dasar basis pengetahuan dari sistem pakar. Perancangan Sistem Pakar Diagnosa Penyakit Mata berbasis web ini mengidentifikasikan permasalahan pada diagnosa awal berdasarkan gejala fisik yang dirasakan atau diderita oleh pasien tanpa melalui pemeriksaan lebih rinci oleh tim medis. Tahapan identifikasi masalah pada Sistem Pakar Diagnosa Penyakit Mata adalah dengan menentukan jenis penyakit beserta gejala yang mempengaruhinya.

\subsection{Gambaran Umum}

Gambaran Umum Sistem merupakan gambaran dari keseluruhan proses yang dilakukan pada sistem serta modul yang nantinya diterapkan ke dalam aplikasi. Gambaran umum Sistem Pakar Diagnosa Penyakit Mata dengan Fuzzy Logic dan Naïve Bayes dijelaskan pada Gambar 1.

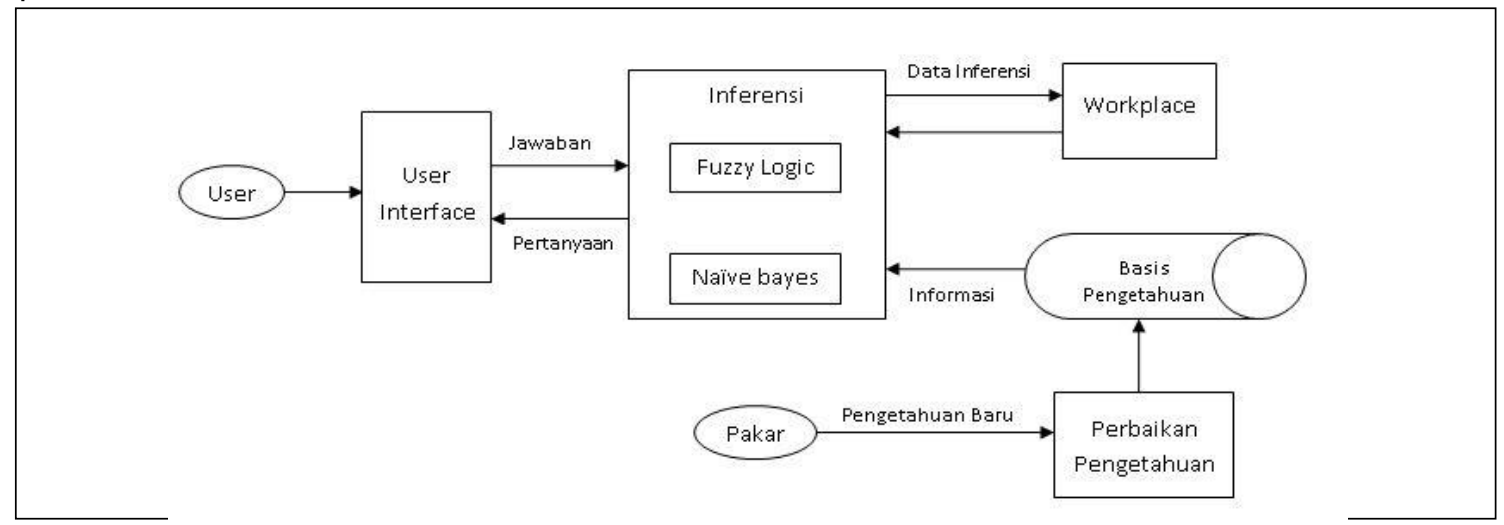

Gambar 1. Gambaran Umum Sistem

Proses konsultasi diawali dengan melakukan identifikasi masalah melalui pertanyaan yang diajukan oleh sistem. Pertanyaan yang diajukan diperoleh dari data gejala penyakit yang telah melalui proses akuisisi pengetahuan. Gejala yang diperoleh dari pengguna diproses melalui dua metode yaitu Naïve Bayes dan Fuzzy Logic. Hasil tertinggi dari pemrosesan ditampilkan melalui interface sehingga pengguna dapat memperoleh hasil berdasarkan kedua metode.

\section{Kajian Pustaka}

Kajian pustaka adalah sekumpulan teori dasar yang digunakan dalam mengembangkan Sistem Pakar Diagnosa Penyakit Mata dengan Fuzzy Logic dan Naïve Bayes.

\subsection{Sistem Pakar}

Keahlian seorang pakar dapat digunakan untuk menyelesaikan banyak masalah dari yang tidak terstruktur hingga masalah yang begitu kompleks. Keahlian tersebut dapat dituangkan dalam sistem pakar atau sistem cerdas lainnya. Sistem pakar adalah salah satu hasil perkembangan teknologi yang dikembangkan dengan tujuan untuk meniru kemampuan seorang pakar di bidang tertentu [4]. Sistem pakar (Expert System) dibuat dengan tujuan untuk 
dapat menyelesaikan masalah yang cukup rumit yang sebenarnya hanya dapat diselesaikan oleh para ahli. Pembuatan sistem pakar bukan untuk menggantikan peran dari ahli itu sendiri melainkan dapat digunakan sebagai asisten yang handal sangat berpengalaman [5].

\subsection{Fuzzy Logic}

Logika Fuzzy digunakan sebagai cara untuk memetakan masalah dari input menuju output yang sesuai. Himpunan fuzzy terletak pada rentang 0 sampai 1 [6]. Logika Fuzzy merupakan suatu logika yang memiliki nilai kekaburan atau kesamaran antara benar atau salah [7]. Himpunan Fuzzy dapat dikembangkan menjadi logika fuzzy. Himpunan tegas atau disebut juga crisp set merupakan himpunan klasik yang umumnya digunakan. Nilai keanggotaan suatu anggota $x$ dalam suatu himpunan A memiliki dua kemungkinan yaitu satu (1) yang berarti bahwa suatu item menjadi anggota dalam suatu himpunan, atau nol (0) yang berarti bahwa suatu item tidak menjadi anggota dalam suatu himpuan [5]. Keanggotaan suatu unsur dinyatakan tegas dalam suatu himpunan apabila anggota tersebut didefinisikan dalam himpunan tersebut [8].

Fungsi keanggotaan adalah sebuah kurva yang menunjukkan pemetaan titik input ke dalam sebuah nilai keanggotaan atau sering juga disebut derajat keanggotaan yang memiliki interval 0 sampai 1 . Cara yang bisa digunakan untuk memperoleh nilai keanggotaan adalah dengan menggunakan pendekatan fungsi. Beberapa fungsi yang digunakan yaitu:

1. Representasi linier

Representasi linier adalah pemetaan input dari derajat keanggotaan yang digambarkan dengan sebuah garis lurus. Himpunan fuzzy linier memiliki dua keadaan yaitu:

a. Representasi Linier Naik

Representasi linier naik merupakan kenaikan himpunan yang dimulai dengan domain yang memiliki nilai keanggotaan nol (0) bergerak ke kanan menuju nilai domain yang memiliki nilai keanggotaan yang lebih tinggi.

$$
\mu[x]\left\{\begin{array}{cc}
0 ; & x \leq a \\
\frac{(x-a)}{b-a} ; & a \leq x \leq b \\
1 ; & x \geq b
\end{array}\right\} .
$$

b. Representasi Linier Turun

Representasi linier turun merupakan penurunan himpunan yang dimulai dengan domain yang memiliki nilai keanggotaan tertinggi pada sisi kiri yang bergerak ke kanan menuju nilai domain yang memiliki nilai keanggotaan yang lebih rendah.

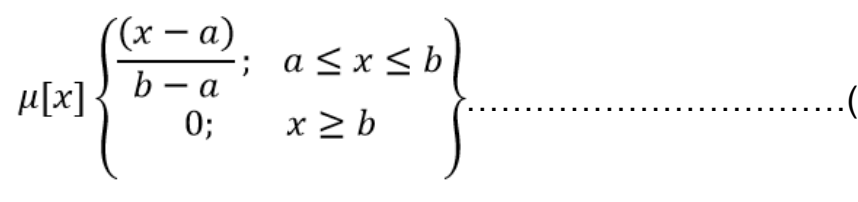

c. Representasi Kurva Segitiga

Representasi kurva segitiga merupakan gabungan dari dua garis linier yaitu linier naik dan linier turun.

$$
\mu[x]\left\{\begin{array}{c}
0 ; x \leq a \text { atau } x \geq c \\
\frac{(x-a)}{(b-a)} ; \quad a \leq x \leq b \\
\frac{(b-x)}{(c-b)} ; b \leq x \leq c
\end{array}\right\} \ldots \ldots \ldots \ldots \ldots \ldots \ldots(3)
$$

\subsection{Naïve Bayes}

Naïve Bayes pertama kali dikemukakan oleh ilmuwan Inggris Thomas Bayes, yaitu memprediksi probabilitas masa depan berdasarkan pengalaman dimasa lalu. Naïve Bayes merupakan algoritma yang memanfaatkan teori probabilitas berdasarkan pada Teorema Bayes dan dikombinasikan dengan "Naïve" yang berarti setiap atribut atau variabel memiliki sifat 
bebas (independent) atau disebut juga sebagai asumsi bebas. Naïve bayes menghitung peluang suatu kelas berdasarkan pada atribut yang dimiliki dan menentukan kelas yang memiliki probabilitas paling tinggi [9]. Keuntungan dari klasifikasi adalah bahwa Naïve Bayes hanya membutuhkan sejumlah kecil data pelatihan untuk memperkirakan parameter (sarana dan varians dari variabel) yang diperlukan untuk klasifikasi. Hanya variasi dari variabel untuk masing-masing kelas harus ditentukan karena variabel independen diasumsikan, bukan seluruh matriks kovarians. Teorema Bayes menyatakan:

$P(\mathrm{~B} \mid \mathrm{A})=\frac{\mathrm{P}(A B) P(B)}{\mathrm{P}(\mathrm{A})}$

dimana:

$P(B \mid A)$

$P(B \mid A)$

$P(B)$

$P(A)$

= Peluang $B$ jika diketahui keadaan jenis penyakit mata $A$

= Peluang evidence A jika diketahui hipotesis $\mathrm{B}$.

= Probabilitas hipotesis $\mathrm{B}$ tanpa memandang evidence apapun.

= Peluang evidence penyakit mata $\mathrm{A}$.

persamaan (4) dapat ditulis menggunakan teorema Bayes sebagai berikut.

Vmap $=\operatorname{argmax}_{v j \in V} \mathrm{P}(\mathrm{vj} \mid \mathrm{a} 1, \mathrm{a} 2, \mathrm{a} 3, \ldots$, an $\mid \mathrm{vj}) \mathrm{P}(\mathrm{vj})$

dimana:

Vmap $\quad=$ Probabilitas Tertinggi

$\mathrm{P}(\mathrm{vj}) \quad=$ Peluang jenis penyakit mata ke $\mathrm{j}$

$\mathrm{P}(\mathrm{a} 1, \mathrm{a} 2, . ., \mathrm{an} \mid \mathrm{vj})=$ Peluang atribut input jika diketahui keadaan $\mathrm{vj}$

Perhitungan $P(v j|a 1, a 2, a 3, \ldots, a n| v j) P(v j)$ bisa menjadi semakin sulit karena jumlah gejala $P(v j|a 1, a 2, a 3, \ldots, a n|$ vj $) P(v j)$ bisa jadi sangat besar. Jumlah gejala yang besar disebabkan karena jumlah gejala tersebut sama dengan jumlah semua kombinasi gejala dikali dengan jumlah kategori yang ada. Menghitung P(ailvj) dapat menggunakan Rumus 6 .

$$
\begin{aligned}
& \mathrm{P}(\text { ail } \mid \mathrm{vj})=\frac{\mathrm{nc}+\mathrm{m} \cdot \mathrm{p}}{\mathrm{n}+\mathrm{m}} \ldots \ldots \ldots \ldots \ldots \ldots \ldots \ldots \ldots \\
& \text { dimana: } \\
& \mathrm{nc} \quad=\text { Jumlah record pada data learning yang } \mathrm{v}=\mathrm{vj} \text { dan } \mathrm{a}=\mathrm{ai} \\
& \mathrm{p} \quad=1 / \text { banyaknya jenis class } / \text { penyakit } \\
& \mathrm{m} \quad=\text { jumlah parameter/gejala } \\
& \mathrm{n} \quad=\text { jumlah record pada data learning yang } \mathrm{v}=\mathrm{vj} / \text { tiap class }
\end{aligned}
$$

1. Menghitung nilai nc untuk setiap class

2. Menghitung nilai $P(a i \mid v j)$ dan menghitung nilai $P(v j)$

$\mathrm{V}_{\text {map }}=\operatorname{argmax}_{\mathrm{vj} \in \mathrm{V}} \mathrm{P}\left(\mathrm{v}_{\mathrm{j}}\right) \Pi_{\mathrm{i}} \mathrm{P}\left(\mathrm{a}_{\mathrm{i}} \mid \mathrm{v}_{\mathrm{j}}\right)$

$\operatorname{dimana} P($ ai $\mid v j)=\frac{n c+m \cdot p}{n+m}$

3. $\quad$ Menghitung $\mathrm{P}(\mathrm{ai} / \mathrm{vj}) \times \mathrm{P}(\mathrm{vj})$ untuk setiap v

4. Menentukan hasil klasifikasi yaitu $v$ yang memiliki hasil perkalian terbesar

\section{Hasil dan Pembahasan}

Hasil dan pembahasan Sistem Pakar Diagnosa Penyakit Mata dengan Fuzzy Logic dan Naïve Bayes dijelaskan dalam dua tahapan yaitu tahapan perancangan dan tahapan implementasi sistem.

\subsection{Perancangan}

Perancangan Sistem Pakar Diagnosa Penyakit Mata dengan Fuzzy Logic dan Naïve Bayes dimulai dengan diagram konteks yang digunakan untuk menghubungkan entitas eksternal dengan sistem dan struktur database yang digunakan untuk menyimpan data. 
1. Diagram Konteks

Diagram konteks menampilkan hubungan antara semua kesatuan luar yang terlibat didalam sistem serta dimana sebuah sistem digambarkan secara garis besar atau secara umum [1]. Diagram konteks dari Sistem Pakar Diagnosa Penyakit Mata menggambarkan model sistem dengan kesatuan luarnya yang dapat dilihat pada Gambar 2.

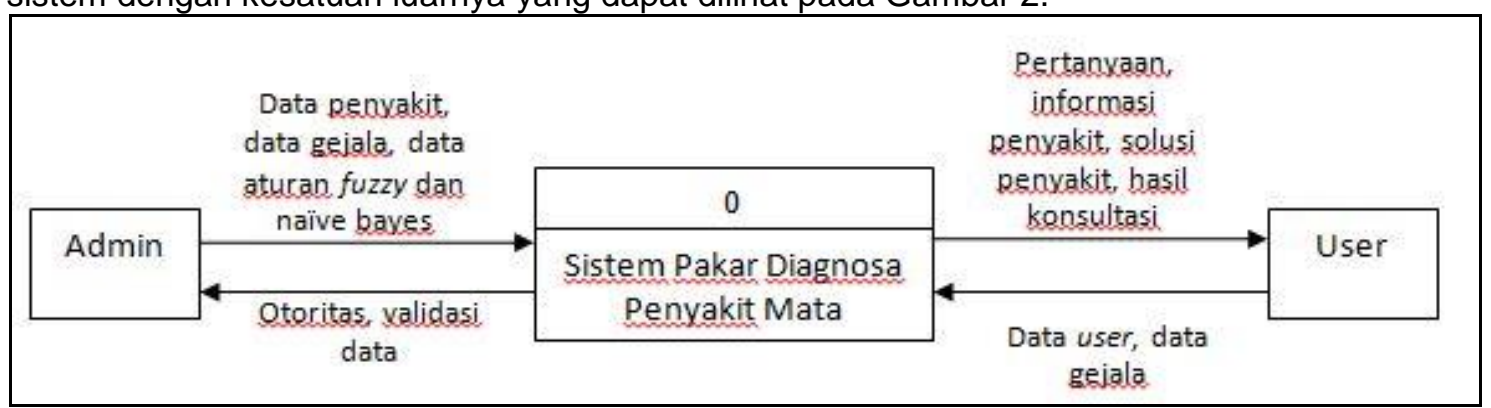

Gambar 2. Diagram Konteks Sistem

Diagram konteks Sistem Pakar Diagnosa Penyakit Mata melibatkan dua entitas yakni User dan Admin. Admin dapat melakukan manipulasi data pada sistem dengan menambah data baru, mengubah data lama serta menghapus data. Data yang dapat dimanipulasi merupakan data yang berkaitan dengan basis pengetahuan sistem pakar seperti data penyakit, data gejala, data fuzzy dan data aturan. User dapat melakukan konsultasi melalui proses membuat akun terlebih dahulu dalam sistem, setelah itu user melakukan proses login sistem. User yang sudah terdaftar dan masuk dapat melakukan proses konsultasi dengan cara menjawab pertanyaan yang diberikan oleh sistem untuk mendapatkan kesimpulan dari gejala yang diderita.

2. Struktur Database

Database adalah kumpulan relasi logical dari data atau deskripsi data yang dapat digunakan bersama dan dibuat untuk memperoleh informasi yang dibutuhkan [10]. Struktur database yang digunakan dalam database Aplikasi Sistem Pakar Diagnosa Penyakit Mata ditunjukkan pada Gambar 3.

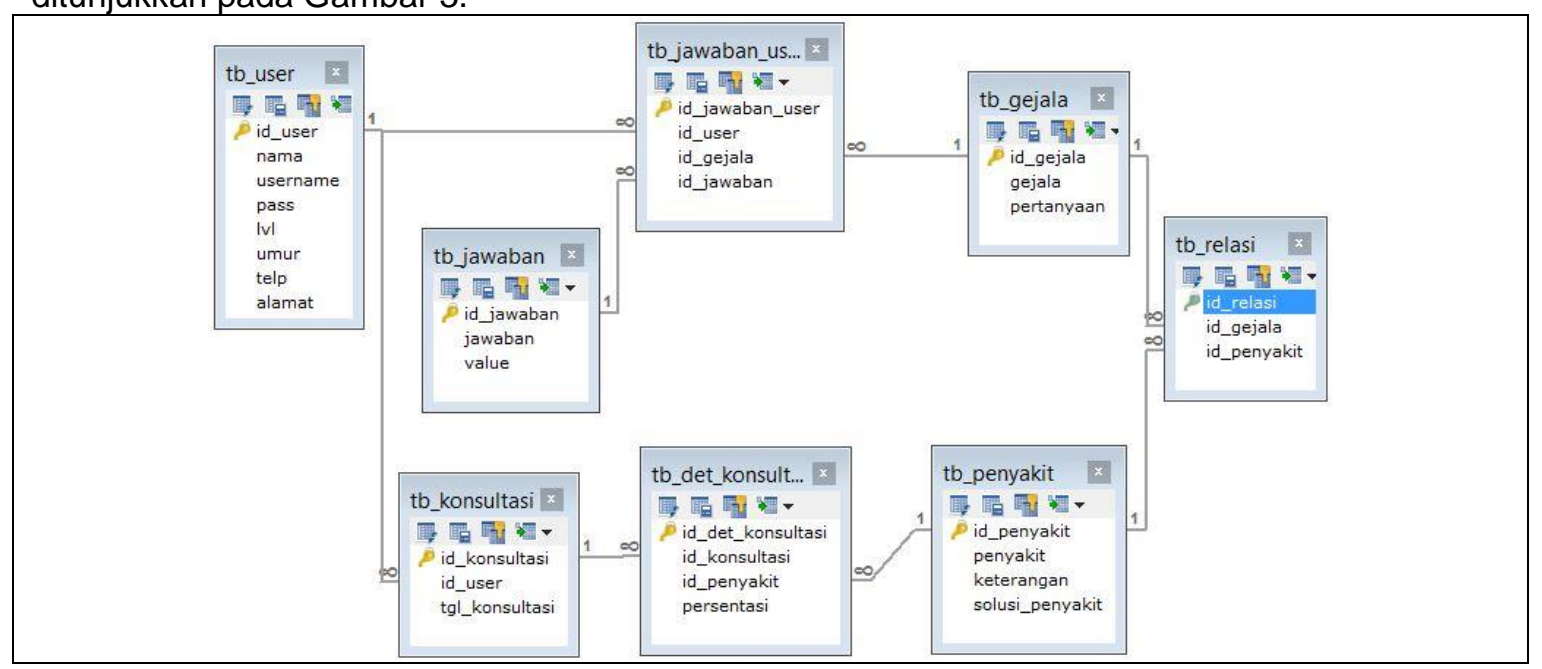

Gambar 3. Struktur Database Sistem

Gambar 3 menunjukkan beberapa tabel pada struktur database sistem yaitu tabel tb_gejala, tb_relasi, tb_penyakit, tb_det_konsultasi, tb_konsultasi, tb_user, tb_jawaban, dan tb_jawaban_user. Tabel tb_gejala berfungsi untuk menyimpan data gejala dari masing-masing penyakit. Tabel tb_penyakit berfungsi untuk menyimpan data penyakit. Tabel tb_user berfungsi untuk menyimpan data pasien. Tabel tb_konsultasi berfungsi untuk menyimpan data konsultasi yang dilakukan pasien. Tabel tb_det_konsultasi berfungsi untuk menyimpan data detail konsultasi yang telah dilakukan oleh pasien. Tabel tb_relasi berfungsi untuk menyimpan data relasi antara penyakit dan gejalanya. Tabel tb_jawaban berfungsi untuk menyimpan data nama 
pilihan jawaban beserta value jawaban. Tabel tb_jawaban_user berfungsi untuk menyimpan data jawaban user saat melakukan konsultasi.

Tabel 1. Bobot Tingkat Keyakinan Jawaban

\begin{tabular}{|c|l|l|}
\hline No & \multicolumn{1}{|c|}{ Pilihan Jawaban } & \multicolumn{1}{c|}{ Tingkat Keyakinan Pakar } \\
\hline 1 & Tidak & 0 \\
\hline 2 & Sedikit & 0.3 \\
\hline 3 & lya & 0.8 \\
\hline 4 & Sangat & 1 \\
\hline
\end{tabular}

Bobot tingkat keyakinan jawaban pada Tabel 1 diperoleh dari Dokter Spesialis Penyakit Mata. Bobot tingkat keyakinan diberikan oleh pakar pada masing-masing pilihan jawaban untuk semua gejala penyakit mata.

\subsection{Implementasi Sistem}

Implementasi sistem merupakan sarana dari pengguna untuk melakukan proses tanya jawab dengan sistem.

\begin{tabular}{|l|l|l|l|}
\hline \multicolumn{1}{|l|}{ Konsultasi } \\
$\qquad$\begin{tabular}{l|l|l|}
\hline Pertanyaan \\
Berapa jarak maksimal anda dapat melihat? (dalam meter)
\end{tabular} \\
\hline \begin{tabular}{ll|l|} 
Apakah anda merasa nyeri pada mata? \\
Apakah mata anda merah?
\end{tabular} \\
\hline
\end{tabular}

Gambar 4. Tampilan Konsultasi Pertanyaan Gejala 1

Gambar 4 menampilkan gejala pandangan kabur, nyeri pada mata dan mata merah. Pasien dapat memberikan salah satu dari empat pilihan jawaban yang disediakan oleh sistem mulai dari "Tidak", "Sedikit", "Iya" dan "Sangat". Pasien memberikan jawaban "Iya" pada pertanyaan untuk gejala mata merah dan nyeri pada mata yang ditunjukkan Gambar 4. Sistem menampilkan pertanyaan dari gejala penglihatan kabur yang jawabannya tidak bisa ditetapkan oleh sistem sehingga pasien harus mengisi kolom jawaban dengan memasukkan nilai jarak pandangan yang masih terlihat jelas oleh mata dalam satuan meter. Jarak pandang pada penglihatan kabur merupakan gejala yang bernilai tidak pasti atau Fuzzy maka dilakukan perhitungan sebagai berikut.

$$
\begin{aligned}
& \mu \text { Sedikit Kabur }(x)=\frac{4,5-4,2}{4,5-3,5}=\frac{0,3}{1,0}=0,30 . \\
& \mu \text { Normal }(x) \quad=\frac{4,2-4}{5-4}=\frac{0,2}{1,0}=0,20 . .
\end{aligned}
$$

Perhitungan 9 dan 10 menjelaskan himpunan keanggotaan Sedikit Rabun lebih besar dengan nilai 0,30 daripada himpunan keanggotaan Normal dengan nilai 0,20 sehingga jawaban dari pasien secara otomatis tergolong dalam pilihan jawaban "Sedikit". Sistem menampilkan pertanyaan selanjutnya berupa mata berair dan mata kering.

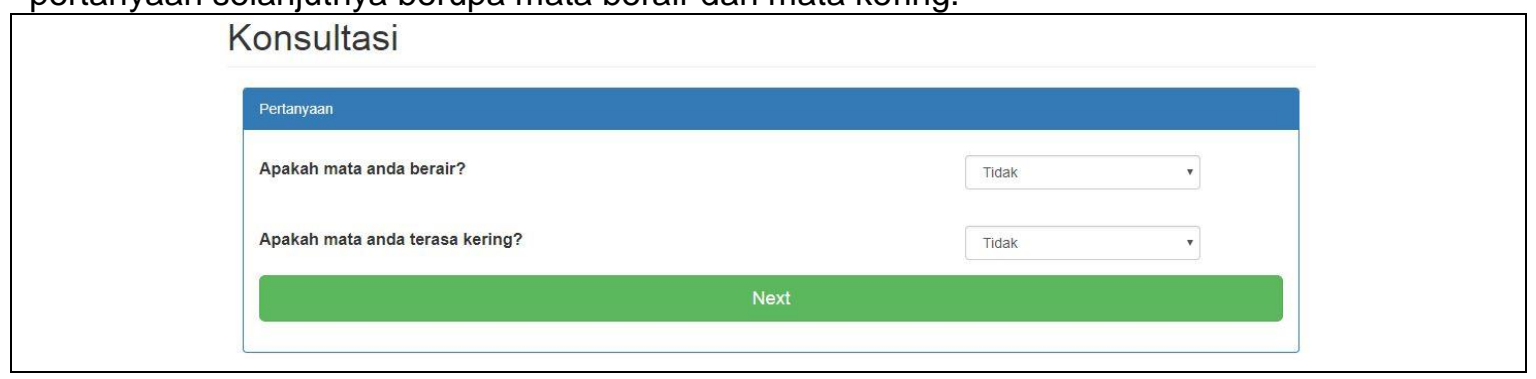

Sistem Pakar Diagnosa Penyakit Mata dengan Fuzzy Logic dan Naïve Bayes 
Gambar 5. Tampilan Konsultasi Pertanyaan Gejala 2

Gambar 5 menunjukkan pasien memberikan jawaban "Tidak" pada pertanyaan untuk gejala mata berair dan mata kering. Sistem selanjutnya menampilkan pertanyaan berupa mata gatal, melihat kilatan cahaya dan pusing atau sakit kepala.

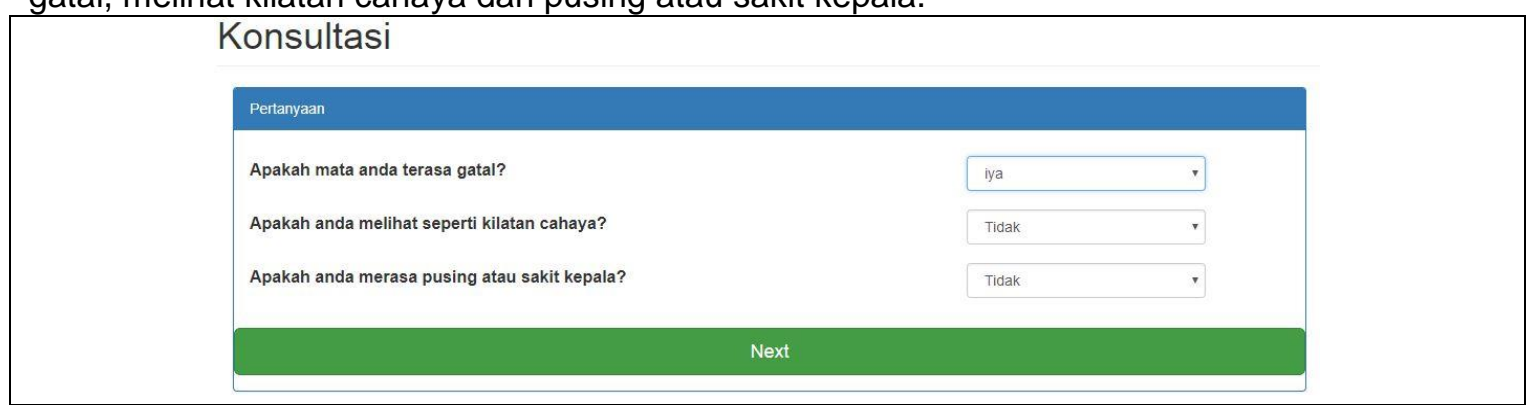

Gambar 6. Tampilan Konsultasi Pertanyaan Gejala 3

Gambar 6 menunjukkan pasien memberikan jawaban "Iya" pada pertanyaan untuk gejala mata gatal dan memberikan jawaban "Tidak" pada pertanyaan untuk gejala melihat kilatan cahaya dan pusing atau sakit kepala. Sistem menampilkan pertanyaan selanjutnya yaitu bengkak pada kantung mata, iritasi pada mata, dan kelopak mata lengket.

\begin{tabular}{|l|l|}
\hline \multicolumn{1}{|l|}{ Konsultasi } \\
$\qquad \begin{array}{l}\text { Pertanyaan } \\
\text { Apakah terdapat bengkak pada kantung mata anda? } \\
\text { Apakah anda merasakan iritasi pada mata? }\end{array}$ \\
\hline Apakah kelopak mata anda lengket? & Tidak \\
\hline
\end{tabular}

Gambar 7. Tampilan Konsultasi Pertanyaan Gejala 4

Gambar 7 menampilkan pasien memberikan jawaban "Tidak" pada pertanyaan untuk gejala bengkak pada kantung mata. Pasien juga memberikan jawaban "lya" pada pertanyaan untuk gejala iritasi pada mata dan jawaban "Sangat" pada pertanyaan untuk gejala kelopak mata lengket. Sistem menampilkan pertanyaan berikutnya yaitu peka terhadap cahaya, tumbuh daging pada mata dan kotoran pada mata.

\begin{tabular}{|l|l|l|}
\hline \multicolumn{1}{|l|}{ Konsultasi } \\
\hline Perianyaan \\
\hline Apakah mata anda peka terhadap cahaya? \\
Apakah pada mata anda tumbuh daging? \\
Apakah terdapat kotoran pada mata anda?
\end{tabular}

Gambar 8. Tampilan Konsultasi Pertanyaan Gejala 5

Gambar 8 menampilkan pasien memberikan jawaban "Tidak" pada pertanyaan untuk gejala peka terhadap cahaya dan tumbuh daging pada mata serta memberikan jawaban "Iya" pada pertanyaan untuk gejala kotoran pada mata. Sistem menampilkan pertanyaan berikutnya berupa benjolan di kelopak mata dan melihat objek asing. 


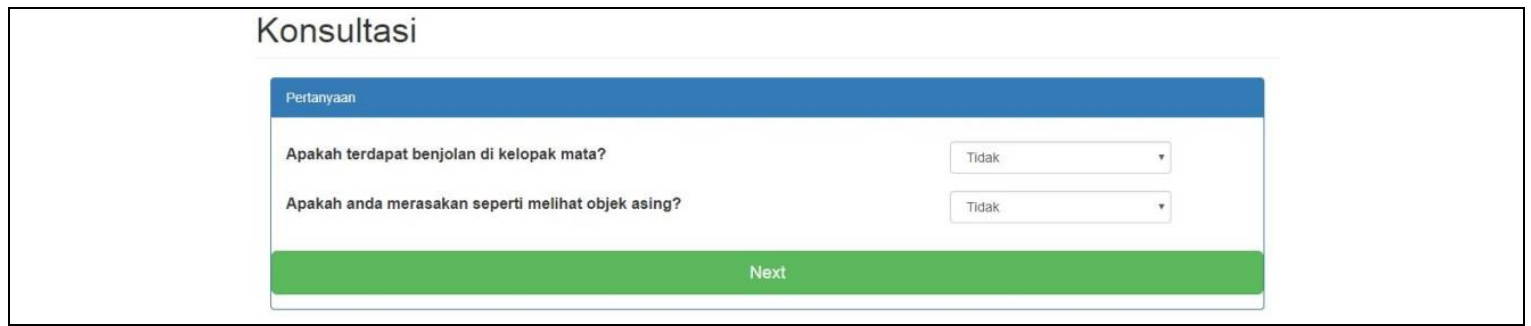

Gambar 9. Tampilan Konsultasi Pertanyaan Gejala 6

Gambar 9 menunjukkan pasien memberikan jawaban "Tidak" pada pertanyaan untuk gejala benjolan di kelopak mata dan melihat objek asing. Sistem berhenti mengajukan pertanyaan karena semua pertanyaan yang diberikan oleh sistem telah terjawab oleh pasien. Hasil diagnosa menampilkan nama penyakit beserta persentase dari penyakit.

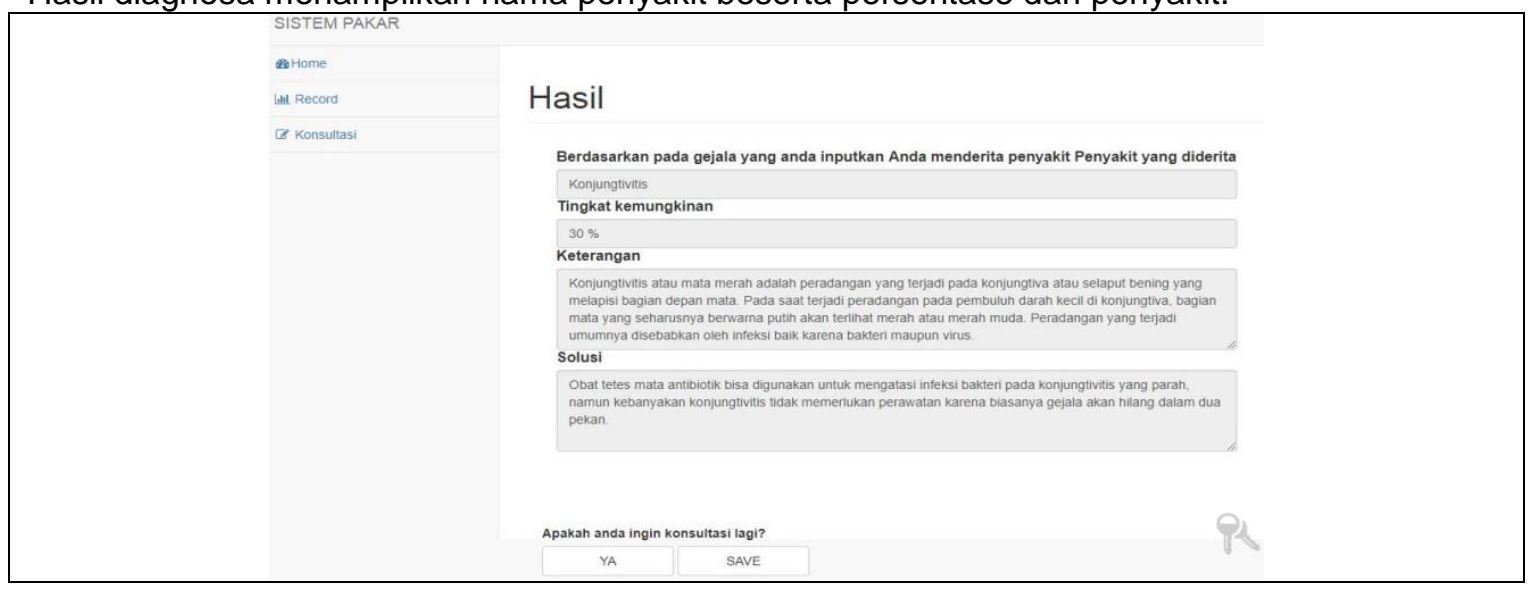

Gambar 10. Tampilan Diagnosa hasil Konsultasi

Gambar 10 menampilkan hasil konsultasi dilengkapi dengan keterangan dari penyakit hasil diagnosa serta solusi awal penanganan penyakit tersebut. Pasien dapat menyimpan hasil konsultasi dengan tombol Save dan melihat hasil konsultasi pada menu Record.

\subsection{Analisa Hasil}

Analisa hasil dilakukan untuk memastikan hasil diagnosa pada sistem pakar memiliki hasil yang sama dan tepat sesuai dengan analisa yang dilakukan oleh pakar. Analisa hasil ditunjukkan seperti pada Tabel 2.

Tabel 2. Ilustrasi jawaban Pasien untuk Penyakit Konjungtivitis

\begin{tabular}{|l|l|l|l|}
\hline No & Nama Gejala & Jawaban Pasien & Nilai Jawaban \\
\hline 1 & Penglihatan kabur & 4.2 & 0,3 \\
\hline 2 & Mata nyeri & lya & 0,8 \\
\hline 3 & Mata merah & lya & 0,8 \\
\hline 4 & Mata gatal & lya & 0,8 \\
\hline 5 & Iritasi mata & lya & 0,8 \\
\hline 6 & Kelopak mata lengket & Sangat & 1 \\
\hline 7 & Kotoran pada mata & lya & 0,8 \\
\hline
\end{tabular}

Perhitungan klasifikasi Naïve Bayes untuk menentukan diagnosa dari gejala yang diinput oleh pasien terdiri dari empat langkah yang dijabarkan sebagai berikut.

1. Menentukan nilai $\mathrm{n}_{\mathrm{c}}$ untuk setiap class

Nilai $n_{c}$ merupakan nilai yang didapat dari mencocokkan semua gejala penyakit pada sistem dengan gejala yang di-input oleh pasien. Sistem memberikan nilai sesuai dengan pilihan jawaban pada setiap gejala penyakit yang cocok dengan gejala penyakit pasien. Gejala penyakit yang tidak cocok dengan gejala penyakit pasien secara otomatis bernilai 0 . Nilai $n_{c}$ yang diperoleh ditunjukkan seperti pada Tabel 3.

Tabel 3. Perhitungan nilai $n_{c}$ untuk setiap class 


\begin{tabular}{|l|l|}
\hline Nama Penyakit & \multicolumn{1}{|c|}{ Perhitungan } \\
\hline & $\mathrm{n} \quad=1$ \\
& $\mathrm{p} \quad=1 / 10=0,1$ \\
& $\mathrm{~m} \quad=16$ \\
$1 \mathrm{n}_{\mathrm{c}}=0,3$ \\
$2 \mathrm{n}_{\mathrm{c}}=0$ \\
$3 \mathrm{n}_{\mathrm{c}}=0$ \\
$7 \mathrm{n}_{\mathrm{c}}=0$ \\
$11 \mathrm{n}_{\mathrm{c}}=0$ \\
& $12 \mathrm{n}_{\mathrm{c}}=0$ \\
& $15 \mathrm{n}_{\mathrm{c}}=0$ \\
\hline & $\mathrm{n}=1$ \\
& $\mathrm{p} \quad=1 / 10=0,1$ \\
& $\mathrm{~m}=16$ \\
& $1 \mathrm{n}_{\mathrm{c}}=0$ \\
& $2 \mathrm{n}_{\mathrm{c}}=0.8$ \\
& $3 \mathrm{n}_{\mathrm{c}}=0.8$ \\
& $7 \mathrm{n}_{\mathrm{c}}=0.8$ \\
& $11 \mathrm{n}_{\mathrm{c}}=0.8$ \\
& $12 \mathrm{n}_{\mathrm{c}}=1$ \\
& $15 \mathrm{n}_{\mathrm{c}}=0.8$ \\
\hline
\end{tabular}

dan seterusnya hingga penyakit mata ke 10 .

2. $\quad$ Menghitung nilai $P\left(a_{i} \mid v_{j}\right)$ dan menghitung nilai $P\left(v_{j}\right)$

Sistem telah memperoleh nilai untuk setiap gejala (a) pada masing-masing penyakit yang cocok dengan gejala masukan dari pasien $\left(a_{i}\right)$. Sistem selanjutnya menghitung nilai $n_{c}$ kedalam rumus $\mathrm{P}(\mathrm{ai} \mid \mathrm{vj})=\frac{\mathrm{nc}+\mathrm{m}_{\mathrm{p}} \mathrm{p}}{\mathrm{n}+\mathrm{m}}$ untuk gejala yang di-input oleh pasien. Menghitung nilai $\mathrm{P}\left(\mathrm{a}_{\mathrm{i}} \mid \mathrm{v}_{\mathrm{j}}\right)$ dan menghitung nilai $\mathrm{P}\left(\mathrm{v}_{\mathrm{j}}\right)$ pada Tabel 4 bertujuan untuk memberikan perolehan nilai untuk gejala yang diberikan pasien pada masing-masing penyakit dalam sistem berdasarkan pada kecocokan antara gejala yang diberikan oleh pasien dan semua gejala dari masingmasing penyakit $\left(\mathrm{v}_{\mathrm{j}}\right)$ yang ada dalam sistem.

Tabel 4. Perhitungan nilai $\mathrm{P}\left(\mathrm{a}_{\mathrm{i}} \mid \mathrm{V}_{\mathrm{j}}\right)$ dan menghitung nilai $\mathrm{P}\left(\mathrm{v}_{\mathrm{j}}\right)$

\begin{tabular}{|l|l|}
\hline Nama Penyakit & \multicolumn{1}{|c|}{ Perhitungan } \\
\hline \multirow{5}{*}{ Refractive Error } & $\mathrm{P}(\mathrm{RE})=1 / \mathrm{RE})=\frac{0,3+16 * 0,1}{1+16}=0,1$ \\
$\mathrm{P}(2 \mid \mathrm{RE})=\frac{0+16 * 0,1}{1+16}=0,0941176470588235$ \\
$\mathrm{P}(3 \mid \mathrm{RE})=\frac{0+16 * 0,1}{1+16}=0,0941176470588235$ \\
$\mathrm{P}(7 \mid \mathrm{RE})=\frac{0+16 * 0,1}{1+16}=0,0941176470588235$ \\
$\mathrm{P}(11 \mid \mathrm{RE})=\frac{0+16 * 0,1}{1+16}=0,0941176470588235$ \\
$\mathrm{P}(12 \mid \mathrm{RE})=\frac{0+16 * 0,1}{1+16}=0,0941176470588235$ \\
$\mathrm{P}(15 \mid \mathrm{RE})=\frac{0+16 * 0,1}{1+16}=0,0941176470588235$ \\
\hline Konjungtivitis & $\mathrm{P}(\mathrm{Ko})=1 / 10 * 0,1=0,1$ \\
$\mathrm{P}(1 \mid \mathrm{Ko})=\frac{0+16 * 0,1}{1+16}=0,0941176470588235$ \\
$\mathrm{P}(2 \mid \mathrm{Ko})=\frac{0,8+16 * 0,1}{1+16}=0,1411764705882353$ \\
$\mathrm{P}(3 \mid \mathrm{Ko})=\frac{0,8+16 * 0,1}{1+16}=0,1411764705882353$ \\
$\mathrm{P}(7 \mid \mathrm{Ko})=\frac{0,8+16 * 0,1}{1+16}=0,1411764705882353$ \\
$\mathrm{P}(11 \mid \mathrm{Ko})=\frac{0,8+16 * 0,1}{1+16}=0,1411764705882353$
\end{tabular}

Sistem Pakar Diagnosa Penyakit Mata dengan Fuzzy Logic dan Naïve Bayes 


\begin{tabular}{|l|l|}
\hline & $P(12 \mid \mathrm{Ko})=\frac{1+16 * 0,1}{1+16}=0,1$ \\
$P(15 \mid \mathrm{Ko})=\frac{0,8+16 * 0,1}{1+16}=0,1411764705882353$
\end{tabular}

dan seterusnya hingga penyakit mata ke 10 .

3. $\quad$ Menghitung $P\left(a_{i} \mid v_{j}\right) \times P\left(v_{j}\right)$ untuk setiap v

Sistem telah mendapatkan hasil dari perhitungan rumus langkah kedua untuk setiap gejala penyakit yang di-input oleh pasien (ai). Langkah selanjutnya adalah mengalikan semua hasil perhitungan gejala penyakit yang di-input oleh pasien $\left(\mathrm{a}_{i}\right)$ untuk masing-masing penyakit. Langkah menghitung $P\left(a_{i} \mid v_{j}\right) \times P\left(v_{j}\right)$ untuk setiap v dilakukan untuk mendapatkan nilai $P\left(v_{j}\right)$ atau peluang untuk masing-masing penyakit.

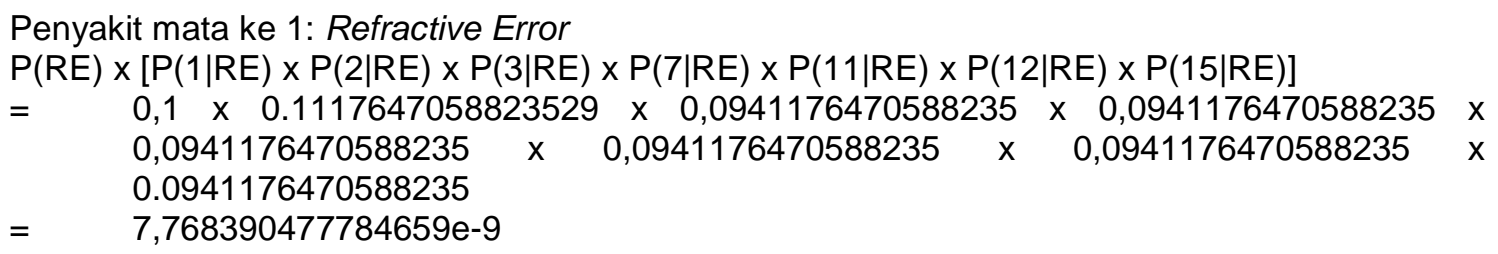

Penyakit mata ke 2: Konjungtivitis

$\mathrm{P}(\mathrm{Ko}) \times[\mathrm{P}(1 \mid \mathrm{Ko}) \times \mathrm{P}(2 \mid \mathrm{Ko}) \times \mathrm{P}(3 \mid \mathrm{K} 0) \times \mathrm{P}(7 \mid \mathrm{Ko}) \times \mathrm{P}(11 \mid \mathrm{Ko}) \times \mathrm{P}(12 \mid \mathrm{Ko}) \times \mathrm{P}(15 \mid \mathrm{Ko})]$

$=0,1 \times 0,0941176470588235 \times 0,1411764705882353 \times 0,1411764705882353 \times$

$0,1411764705882353 \times 0,1411764705882353 \times 0,1 \times 0,1411764705882353$

$=\quad 3,738697629409158 \mathrm{e}-7$

dan seterusnya hingga penyakit mata ke 10 .

4. Menentukan hasil klasifikasi yaitu v yang memiliki hasil perkalian terbesar

Sistem telah mendapatkan perolehan nilai peluang untuk masing-masing penyakit yang ada pada sistem. Nilai peluang untuk setiap penyakit berbeda-beda tergantung dari jawaban pasien dan kecocokan antara gejala dari penyakit dengan gejala yang di-input oleh pasien. Perolehan hasil nilai peluang yang didapatkan setiap penyakit ditampilkan pada Tabel 5.

Tabel 5. Perbandingan Nilai Peluang Setiap Penyakit

\begin{tabular}{|l|l|l|}
\hline No & Nama Penyakit & Nilai Peluang Penyakit \\
\hline 1 & Refractive Error & $7,768390477784659 \mathrm{e}-9$ \\
\hline 2 & Konjungtivitis & $3,738697629409158 \mathrm{e}-7$ \\
\hline 3 & Katarak & $7,768390477784659 \mathrm{e}-9$ \\
\hline 4 & Glaukoma & $1.747887857501549 \mathrm{e}-8$ \\
\hline 5 & Pterigium & $1.747887857501549 \mathrm{e}-8$ \\
\hline 6 & Ablasio Retina & $7,768390477784659 \mathrm{e}-9$ \\
\hline 7 & Dakriosititis & $1,042599774650047 \mathrm{e}-8$ \\
\hline 8 & Oveitis & $1,165258571667699 \mathrm{e}-8$ \\
\hline 9 & Hordeolum & $2,345849492962602 \mathrm{e}-8$ \\
\hline 10 & Keratitis & $3,932747679378489 \mathrm{e}-8$ \\
\hline
\end{tabular}

Sistem memilih satu penyakit dengan nilai peluang paling besar. Penyakit dengan nilai peluang yang paling besar adalah penyakit konjungtivitis dengan nilai peluang 3,738697629409158e-7, maka pasien diklasifikasikan menderita penyakit konjungtivitis. Pemanfaatan dari kombinasi antara Metode Fuzzy Logic dan Naïve Bayes terletak implementasi metode. Implementasi dari Metode Fuzzy Logic dalam sistem pakar yang dihasilkan adalah untuk menangani gejala yang di-input oleh pasien yang bersifat samar seperti jarak pandang mata yang nilainya diisi sendiri oleh pasien. Metode Fuzzy Logic dapat mengubah nilai yang bersifat tidak jelas menjadi nilai yang jelas dengan cara memetakan nilai yang di-input oleh pasien ke dalam himpunan nilai yang telah diberikan oleh pakar.

Nilai yang di-input pasien selanjutnya diproses sehingga menghasilkan nilai yang jelas. Implementasi Metode Naïve Bayes dalam sistem adalah untuk menghitung probabilitas dari setiap nilai gejala yang di-input pasien untuk suatu penyakit. Hasil dari diagnosa bervariasi 
tergantung dari pilihan jawaban pasien. Hasil diagnosa yang bervariasi disebabkan oleh jawaban yang di-input oleh pasien dimana pasien diharuskan untuk menjawab seluruh pertanyaan yang disediakan oleh sistem pakar. Nilai jawaban terhadap gejala yang ditanyakan diproses sehingga menghasilkan satu nilai akhir yang menunjukkan probabilitas pasien menderita penyakit tertentu.

Tabel 6. Perbandingan Diagnosa Antara Sistem dan Dokter

\begin{tabular}{|c|c|c|c|c|}
\hline No. & Gejala & Jawaban & Diagnosa Sistem & Diagnosa Pakar \\
\hline \multirow{6}{*}{1} & Jarak pandang & 3 meter & \multirow{6}{*}{ Pterigium } & \multirow{6}{*}{ Pterigium } \\
\hline & Mata nyeri & Sedikit & & \\
\hline & Mata gatal & lya & & \\
\hline & Melihat kilatan cahaya & lya & & \\
\hline & Kepala terasa pusing & Sedikit & & \\
\hline & Tumbuh daging & Sangat & & \\
\hline \multirow{5}{*}{2} & Jarak pandang & 4 meter & \multirow{5}{*}{ Refractive Error } & \multirow{5}{*}{ Refractive Error } \\
\hline & Mata berair & Sedikit & & \\
\hline & Melihat kilatan cahaya & Sedikit & & \\
\hline & Kepala terasa pusing & lya & & \\
\hline & Peka terhadap cahaya & Sedikit & & \\
\hline \multirow{4}{*}{3} & Jarak pandang & 0,5 meter & \multirow{4}{*}{ Oveitis } & \multirow{4}{*}{ Oveitis } \\
\hline & Mata merah & Sangat & & \\
\hline & Mata nyeri & Sangat & & \\
\hline & Kepala terasa pusing & Sangat & & \\
\hline \multirow{3}{*}{4} & Jarak pandang mata & 3 meter & \multirow{3}{*}{ Oveitis } & \multirow{3}{*}{ Glaukoma } \\
\hline & Mata nyeri & Sedikit & & \\
\hline & Kepala terasa pusing & lya & & \\
\hline \multirow{3}{*}{5} & Jarak pandang mata & 2 meter & \multirow{3}{*}{ Refractive Error } & \multirow{3}{*}{ Ablasio Retina } \\
\hline & Melihat kilatan cahaya & Sangat & & \\
\hline & Melihat objek asing & lya & & \\
\hline \multirow{5}{*}{6} & Jarak pandang mata & 4 meter & \multirow{5}{*}{ Keratitis } & \multirow{5}{*}{ Keratitis } \\
\hline & Mata merah & lya & & \\
\hline & Mata gatal & lya & & \\
\hline & Iritasi mata & Iya & & \\
\hline & Benjolan kelopak mata & Sedikit & & \\
\hline \multirow{3}{*}{7} & Jarak pandang mata & 2,5 meter & \multirow{3}{*}{ Pterigium } & \multirow{3}{*}{ Pterigium } \\
\hline & Mata kering & Sedikit & & \\
\hline & Peka terhadap cahaya & lya & & \\
\hline \multirow{4}{*}{8} & Jarak pandang mata & 3 meter & & \\
\hline & Melihat kilatan cahaya & Sedikit & Rofroctive orror & Rofractivo orror \\
\hline & Peka terhadap cahaya & lya & Retractive error & Retractive error \\
\hline & Melihat objek asing & Sedikit & & \\
\hline & Jarak pandang mata & 5,5 meter & & \\
\hline & Mata nyeri & lya & & \\
\hline 0 & Mata berair & Sangat & Karntitio & Ratruingititi \\
\hline$y$ & Mata kering & Sedikit & Kerattis & Dakriosittis \\
\hline & Bengkak kantung mata & Iya & & \\
\hline & Mata lengket & sedikit & & \\
\hline & Jarak pandang mata & 6 meter & & \\
\hline 10 & Mata berair & lya & Keratitic & Keratitic \\
\hline 10 & Kelopak mata lengket & lya & Neratilis & Kerattis \\
\hline & Kotoran pada mata & Sangat & & \\
\hline & Jarak pandang mata & 4,8 meter & & \\
\hline 11 & Mata kering & lya & Pteriaium & Pterigium \\
\hline 11 & Sakit kepala & lya & riengium & r tengunin \\
\hline & Peka terhadap cahaya & Sedikit & & \\
\hline 12 & Jarak pandang mata & 5 meter & Pyoitir & Ouitin \\
\hline 12 & Mata merah & lya & Uveitis & Uveltis \\
\hline
\end{tabular}




\begin{tabular}{|l|c|c|c|c|}
\hline & Sakit kepala & lya & \multirow{4}{*}{} & \multirow{2}{*}{} \\
\cline { 2 - 3 } & Benjolan kelopak mata & Sedikit & \multirow{4}{*}{} \\
\cline { 2 - 3 } & Melihat objek asing & Sedikit & & \\
\hline
\end{tabular}

Pengujian pada Tabel 6 yang dilakukan oleh pakar dan hasil diagnosa pada sistem terhadap 12 diagnosa menunjukkan perbedaan diagnosa sebanyak tiga kali dan kesamaan diagnosa sebanyak sembilan kali. Hasil yang diperoleh memperlihatkan bahwa sistem pakar yang dibuat memiliki tingkat keakuratan dengan diagnosa yang dilakukan oleh pakar sebesar $81 \%$. Sistem hanya bisa digunakan untuk melakukan diagnosa awal penyakit mata karena untuk mendapatkan hasil diagnosa yang akurat, pasien harus melalui serangkaian pemeriksaan lebih lanjut serta penanganan khusus dari dokter dan alat laboratorium.

\section{Kesimpulan}

Sistem Pakar Diagnosa Penyakit Mata diimplementasikan berbasis web dengan menggunakan Bahasa Pemrograman PHP dan HTML. Implementasi Fuzzy Logic pada aplikasi adalah untuk membantu menghasilkan jawaban dengan nilai pasti dari nilai tidak pasti yang diberikan oleh pasien. Implementasi Naïve Bayes pada aplikasi adalah untuk menghitung probabilitas penyakit yang diderita oleh pasien berdasarkan kecocokan gejala yang di-input oleh pasien dengan gejala yang ada dalam sistem. Sistem pakar diagnosa penyakit Mata telah diuji oleh seorang pakar dan dapat memberikan tingkat kesamaan diagnosa pakar dengan sistem sebesar $81 \%$.

\section{Daftar Pustaka}

[1] N. Putu, R. Gangga, O. Sudana, and I. M. Sukarsa, "Implementasi Diagram Tree pada Rancang Bangun Sistem Informasi Bebayuhan Oton Berbasis Web," Lontar Komputer, vol. 8, no. 3, pp. 178-187, 2017.

[2] P. M. Prihatini, I. K. Gede, and D. Putra, "Fuzzy Knowledge-based System with Uncertainty for Tropical Infectious Disease Diagnosis," IJCSI International Journal of Computer Science Issues, Vol. 9, Issue 4, No 3, July 2012, vol. 9, no. 4, pp. 157-163, 2012.

[3] I. M. Prawita, "SISTEM PAKAR PENYAKIT PADA ABDOMEN DENGAN CERTAIN FACTOR," Merpati, vol. 4, no. 2, pp. 1-10, 2016.

[4] D. P. S. Dewi, "Sistem Pakar Diagnosa Penyakit Jantung dan Paru dengan Fuzzy Logic dan Certainty Factor," Merpati Vol. 2, No. 3, Desember 2014, vol. 2, no. 3, pp. 361-370, 2014.

[5] S. Kusumadewi, Artificial Intelligence (Teknik dan Aplikasinya). Yogyakarta: Graha IImu, 2003.

[6] R. Kaur and A. Kaur, "Hypertension Diagnosis Using Fuzzy Expert System," International Journal of Engineering Research and Applications, no. March, pp. 14-18, 2014.

[7] I. P. B. Krisnawan, I. K. G. D. Putra, and I. P. A. Bayupati, "Sistem Pakar Diagnosa Penyakit Kulit dan Kelamin dengan Metode Certainty Factor dan Fuzzy Logic," Merpati, vol. 2, no. 3, pp. 351-360, 2014.

[8] G. A. M. S. Wimatsari, I. K. G. D. Putra, and P. W. Buana, "Multi-Attribute Decision Making Scholarship Selection Using A Modified Fuzzy TOPSIS," International Journal of Computer Science, vol. 10, no. 1, pp. 309-317, 2013.

[9] I. G. A. Socrates, A. L. Akbar, M. S. Akbar, A. Z. Arifin, and D. Herumurti, "Optimasi Naive Bayes dengan Pemilihan Fitur dan Pembobotan Gain Ratio," Lontar Komputer: Jurnal IImiah Teknologi Informasi, vol. 7, no. 1, p. 22, 2016.

[10] Harmandya, Mentari, Gusti Made Arya Sasmita, Ni Kadek Ayu Wirdiani, "Rancang Bangun Aplikasi Tryout Ujian Nasional Sekolah Menengah Pertama (SMP) Berbasis Android," Lontar Komputer, vol. 6, no. 2, pp. 108-119, 2015. 